\title{
PROBIOTIC FEATURES OF TWO ORAL LACTOBACILLUS ISOLATES
}

\section{Gordana Zavisic $^{1}$; Sasa Petricevic ${ }^{1}$; Zeljka Radulovic ${ }^{1}$; Jelena Begovic ${ }^{2}$; Natasa Golic ${ }^{2}$; Ljubisa Topisirovic ${ }^{2}$; Ivana Strahinic $^{2^{*}}$}

${ }^{1}$ Galenika a.d. Institute for R\&D, Batajnički drum bb, 11080 Belgrade, Serbia; ${ }^{2}$ Institute of Molecular Genetics and Genetic Engineering, University of Belgrade, Vojvode Stepe 444a, P. O. Box 23, 11010 Belgrade, Serbia.

\begin{abstract}
In this study, we checked lactobacilli strains of human origin for their potential as probiotic. Samples were collected from oral mucosa of 16 healthy individuals, out of which twenty isolates were obtained and two of them were selected and identified as Lactobacillus plantarum (G1) and L. casei (G3). Both isolates exhibited antagonistic action towards pathogenic microorganisms such as Staphylococcus aureus, Pseudomonas aeruginosa, Escherichia coli, Salmonella abony, and Clostridium sporogenes, but not on the growth of Candida albicans. The bacteriocin activity against Staphylococcus aureus ATCC 6358-P was shown only by L. plantarum G1. Moreover, the isolates G1 and G3 showed good viability in the acid gastric environment and in the gut environment containing bovine bile salts. The viability of G1 and G3 isolates in the gastrointestinal tract, and the adhesion to the intestinal mucosa were also confirmed in vivo. The biochemical tests of blood samples revealed lower levels of serum triglycerides and cholesterol, as well as reduced activity of alkaline phosphatase in all lactobacilli-treated Wistar rats, compared to control ones. No toxicity for NMRI Ham mice was observed. According to our experimental results, these findings imply that $L$. plantarum $\mathrm{G} 1$ and $L$. casei $\mathrm{G} 3$ could be characterized as potential probiotics.
\end{abstract}

Key word: Lactobacillus, probiotics, antimicrobial activity, hipolypemic effect

\section{INTRODUCTION}

According to definition of probiotic recommended by FAO/WHO, probiotics are live microorganisms, which when administered in adequate amounts confer a health benefit on the host (13). Bacterial species that are currently of commercial interest as probiotics mainly belong to the genus Lactobacillus and Bifidobacterium $(8,20,33)$. Their use in the recommended doses is safe for humans. However, some health risks could exist although they are very sparse and mostly detected in immunocompromised persons $(17,23)$. It is known that 700 to 1000 different bacterial species reside in the human intestines (18). Among them, Lactobacillus sp. pertains to the subdominant gastrointestinal microbiota (27).

\footnotetext{
*Corresponding Author. Mailing address: Institute of Molecular Genetics and Genetic Engineering, University of Belgrade, Vojvode Stepe 444a, Belgrade, Serbia.; Tel.: (+381) 113975960 Fax: (+381) 113975 808.; E-mail: strahi@imgge.bg.ac.rs
} 
In particular, Lactobacillus species found in the gastrointestinal tract have received tremendous attention due to their health-promoting properties (39). Their useful action on the intestinal microbiota results in the protection of the human body from pathogens through different mechanisms, including competitive binding to the intestinal mucosa and production of antimicrobial substances, such as organic acid, primary lactic acid, carbon dioxide, and bacteriocin $(3,4)$. In addition, they are used for the prevention and treatment of gastrointestinal disorders, overcoming intolerance to lactose, the host immune responses modulation, and prevention of cancer (22). Also, they showed a protective action against cardiovascular diseases through the reduction of serum cholesterol and triglyceride levels, the removal of cholesterol by the cholesterol micelles and precipitation of the cholesterol with bile acids $(1,40)$.

In view of all these facts, the purpose of this study was to isolate and characterize the lactobacilli originating from the human oral mucosa, as well as to evaluate their probiotic and some functional properties like their effects on serum lipids content and the alkaline phosphatase (ALP) activity. The main contribution of these investigations is discovering new potential probiotic strains that could eventually be usefully applied in practice.

\section{MATERIALS AND METHODS}

\section{Bacterial isolation methods}

MRS medium (DeMan-Rogosa-Sharpe; Merck GmbH, Darmstadt, Germany) was used for isolation, multiplication, and recovery of lactobacilli. The oral mucosa material was obtained from 16 healthy subjects between 10 and 50 years of age. Each swab was suspended in $10 \mathrm{ml}$ of phosphate buffer with $0.05 \%$ cystein and homogenised for $2 \mathrm{~min}$. A set of 10 fold dilutions was made in the sterile phosphate buffer, $\mathrm{pH}$ 7.2. Subsequently, $100 \mu \mathrm{l}$ of each dilution was smeared on the surface of MRS agar (Merck). The inoculated plates were incubated at $37^{\circ} \mathrm{C}$ in the anaerobic environment (Gas pack vessel, BioMerieux, France) for 72 h. Individual colonies were stickled on fresh MRS plates and used as the starting material for bacterial assessment.

\section{Strains, media, and growth conditions}

Staphylococcus aureus ATCC 6538-P, Escherichia coli ATCC 8739, Pseudomonas aeruginosa ATCC 9027, Salmonella abony NTCC 6017, Bacillus cereus ATCC 11778, Clostridium sporogenes ATCC 19404, Candida albicans ATCC 10231, and Enterococcus sp. were grown on selective media, such as: Baird Parker medium for $S$. aureus, MacConkey medium for E. coli, Deoxycholate lactose medium for $S$. abony, Cetrimide medium for $P$. aeruginosa, Sulphate medium for $C$. sporogenes, Sabouraud dextrose medium for $C$. albicans, and Bile esculin medium for enterococci. Agar plates were prepared by adding agar $(1.5 \%$, w/v) (Torlak, Belgrade, Serbia) to each broth when used as a solid medium. C. albicans was incubated at $25^{\circ} \mathrm{C}$ for $72 \mathrm{~h}$. The other listed strains were incubated at $37^{\circ} \mathrm{C}$ for $48 \mathrm{~h}$. Triptone soy broth (TSB) was used for cultivation of lactobacilli in mixed culture with pathogenic bacteria. The above-mentioned media were obtained from Torlak.

\section{Identification of lactobacilli isolates}

All isolates were preliminary identified as lactobacilli, using the following physiological tests: the growth at different temperatures $\left(15^{\circ} \mathrm{C}, 30^{\circ} \mathrm{C}, 37^{\circ} \mathrm{C}\right.$ and $\left.45^{\circ} \mathrm{C}\right)$ in MRS broth for 5 days; the growth in MRS broth with $2 \%, 4 \%$ and $6.5 \%(\mathrm{w} / \mathrm{v})$ $\mathrm{NaCl}$ for 5 days; $\mathrm{CO}_{2}$ production from glucose in MRS broth lacking beef extract and containing inverted Durham's tubes; L-arginine and esculin hydrolysis, and growth in $10 \%$ skimmed milk medium (38). The biochemical identification of lactobacilli isolates was carried out by standard API 50CH test performed in accordance with the manufacturer's procedure (Bio-Merieux, Montalien-Vecien, France). API ZYM was used for testing the enzymatic activity of bacteria. All tests were performed in triplicates. 


\section{DNA isolation and manipulations}

Lactobacilli genomic DNA was isolated using the QIA DNA Mini Kit (Qiagen GmbH, Hilden, Germany). PCR amplicons were generated using Taq polymerase (Pharmacia, Vienna, Austria), according to the supplier's instructions. PCR products were analyzed on $1 \%$ agarose gels and purified using the QIAquick gel extraction kit (Qiagen GmbH, Hilden, Germany). Species determination was done by PCR, using primers complementary to $16 \mathrm{~S}$ rDNA: UNI16SF (5'-GAG AGT TTG ATC CTG GC-3) and UNI16SR (5'-AGG AGG TGA TCC AGC CG-3'). PCR amplifications were performed by using the GeneAmp PCR System 2700 thermal cycler (Applied Biosystems, Foster City, CA, USA) and Taq polymerase (Pharmacia, Vienna, Austria). PCR amplifications were carried out in tubes containing $25 \mu 1$ reaction mixture composed of 1xTaq buffer, $1 \mathrm{U}$ Taq polymerase, $1.5 \mathrm{mmol}$ $\mathrm{MgCl}_{2}, 200 \mu \mathrm{mol}$ dNTPs each and $1.5 \mu \mathrm{mol}$ primer each. PCR amplification conditions were as follows: $5 \mathrm{~min}$ at $96^{\circ} \mathrm{C} ; 30$ cycles of $96^{\circ} \mathrm{C}$ for $30 \mathrm{~s}, 55^{\circ} \mathrm{C}$ for $30 \mathrm{~s}$, and $72^{\circ} \mathrm{C}$ for $30 \mathrm{~s}$, and an additional extension step of $5 \mathrm{~min}$ at $72^{\circ} \mathrm{C}$. Resulting PCR amplicons were purified with QIAGENE PCR Purification Kit (QIAGEN GmbH Hilden, Germany), following the manufacturer's instruction. Sequencing was done in Central Service of Macrogen (Macrogen, Seoul, South Korea) by using the dideoxynucleotide DNA chain termination method. The BLAST algorithm (http://www.ncbi.nlm.nih.gov/BLAST; RID: 1138633900-27581-131272740575. BLASTQ4) was used to determine the most related sequence relatives in the NCBI nucleotide sequence database. For the final L. plantarum determination, a multiplex PCR assay with the recA gene based specific primers plantF, paraF, pentF, and pREV was performed as previously described (37).

\section{Agar-well diffusion assay}

The overnight cultures of the indicator strains were mixed at $1 \%\left(10^{6} \mathrm{CFU} / \mathrm{ml}\right)$ with melted nutrient agar poured in sterile Petri dishes and allowed to solidify. A 6-mm wide well was cut in the agar across the centre of the dish. Aliquots $(100 \mu \mathrm{l})$ of cell-free filtrate of the lactobacilli overnight cultures $(18 \mathrm{~h})$ were poured in the wells. The plates were first incubated at $4{ }^{\circ} \mathrm{C}$ for $2 \mathrm{~h}$ to allow the test material to diffuse in the agar and then incubated for $18 \mathrm{~h}$ at the specified temperature. After the incubation, a clear zone of inhibition around the well was measured. To detect the antimicrobial activity, the following indicator strains were used: S. aureus ATCC 6538-P, E. coli ATCC 8739, P. aeruginosa ATCC 9027, S. abony NTCC 6017, B. cereus ATCC 11778, C. sporogenes ATCC 19404, and $C$. albicans ATCC 10231.

\section{Bacteriocin assay}

The overnight cultures of the G1 and G3 strains were pelleted and the $\mathrm{pH}$ of supernatants was adjusted to 7.0. The neutralized supernatants were passed through a sterile microbiological filter $(0.45 \mu \mathrm{m})$ and treated with $1 \mathrm{mg} / \mathrm{ml}$ Proteinase-K (Merck, Darmstadt, Germany) at $37^{\circ} \mathrm{C}$ for 60 min. The wells of the previously prepared Petri plates containing inoculated indicator strain were filled with $100 \mu \mathrm{l}$ of the prepared supernatant. The plates were incubated as described above. The proteinaceous nature of the antimicrobial substances was assessed as the absence of clear inhibition zones around the wells, which is the result of bacteriocin degradation by the added proteinase-K (31). The MRS medium buffered to 7.0 was used as the control.

\section{Quantification of antimicrobial/bacteriocin production}

Pelleted cells were resuspended in $1 \mathrm{ml}$ of MRS, and were used as inoculum for the new culture in MRS broth with approximately $10^{6} \mathrm{CFU} / \mathrm{ml}$. To quantify the yield of antimicrobial/bacteriocin production, unbuffered or neutralized aliquots of cell-free filtrate were serially diluted in MRS broth before loading $100 \mu \mathrm{l}$ of each dilution onto indicator strains. The activity of each dilution was determined by agar-well diffusion assay. Antimicrobial/bacteriocin activity was expressed as arbitrary units (AU/ml). One arbitrary unit of 
antimicrobial/bacteriocin was defined as the reciprocal of the highest dilution showing a clear zone of growth inhibition on the indicator lawn. Quantification of antimicrobial/bacteriocin production was done in duplicate, variation of $\mathrm{AU}$ values was less than $5 \%$.

\section{The effect of $L$. plantarum G1 and $L$. casei G3 on $S$. aureus} ATCC 6538-P, E. coli ATCC 8739 and S. abony NTCC 6017 growth in mixed cultures

To test the effect of single or mixed cultures of $L$. plantarum G1 and L. casei G3 on the growth of pathogenic strains, the TSB medium was initially inoculated with lactobacilli $\left(10^{7} \mathrm{CFU} / \mathrm{ml}\right)$ or single inoculations and $10^{7}$ $\mathrm{CFU} / \mathrm{ml}$ or $10^{10} \mathrm{CFU} / \mathrm{ml}$ when mixed cultures of $\mathrm{G} 1$ and $\mathrm{G} 3$ were used. The ratio of mixed lactobacilli G1 and G3 was 1:1. Subsequently, S. aureus ATCC 6538-P (10 5 CFU/ml), E. coli ATCC $8739\left(10^{7} \mathrm{CFU} / \mathrm{ml}\right)$, and S. abony NTCC $6017\left(10^{4}\right.$ $\mathrm{CFU} / \mathrm{ml}$ ) were added and obtained cultures were incubated under agitation $(100 \mathrm{rpm})$ at $37^{\circ} \mathrm{C}$ during $24 \mathrm{~h}$. Pure cultures of pathogenic strains served as a control. To determine the number of viable cells $(\mathrm{CFU} / \mathrm{ml})$ by the agar plate count method, the following media were used: Baird Parker agar for S. aureus, MacConkey agar (MCA) for E. coli, Deoxycholate Lactose agar for S. abony, and MRS agar for lactobacilli. The plates were incubated at $37^{\circ} \mathrm{C}$ for $48 \mathrm{~h}$ and each strain count $(\mathrm{CFU} / \mathrm{ml})$ was determined. All the experiments were carried out in triplicates.

\section{Analytical method: HPLC assay of lactic acid in cells free supernatant}

The concentration of lactic acid (LA) was determined by HPLC (HP1100, Hewlett Packard, Palo Alto, CA, USA) with an ion exchange column (Supelcogel C-610H, Supelco, USA) using $0.1 \%(\mathrm{w} / \mathrm{v}) \mathrm{H}_{3} \mathrm{PO}_{4}$ as the mobile phase. The flow rate of the mobile phase was $0.5 \mathrm{ml} / \mathrm{min}$ and absorbance at $210 \mathrm{~nm}$ was measured by a Diode Array Detector (DAD 1100, Hewlett Packard). LA verification was determined by HLPC (LC-6A,
Shimadzu, Kyoto, Japan), with the same column, mobile phase, flow rate and Refraction Index Detector (RID, 9100 Varian, Inc, Palo Alto, CA, USA). The reproducibility was checked by triplicate tests. The system suitability and linearity for concentration of LA was checked by standard organic acid kit (cat. No. 47264, Supelco Inc, Bellefonte, PA, USA) (19).

\section{In vitro testing - resistance to artificial gastric and intestinal fluids}

The test of bacterial survival in artificial gastric juice (AGJ) was performed as follows: $10 \mathrm{ml}$ of MRS medium was inoculated at $1 \%(\mathrm{v} / \mathrm{v})$ with lactobacilli strains and incubated at $37^{\circ} \mathrm{C}$ for $18 \mathrm{~h}$. After washing of the bacterial cells, $10 \mathrm{ml}$ of cell suspension $\left(10^{8} \mathrm{CFU} / \mathrm{ml}\right)$ was added to $90 \mathrm{ml}$ of AGJ $(0.03$ $\mathrm{M} \mathrm{NaCl}, 0.32 \%$ pepsin at $\mathrm{pH} 2.0$ adjusted with $0.58 \mathrm{ml} 10 \mathrm{M}$ $\mathrm{HCl})$ and incubated with gently agitation (58 rpm) to simulate peristalsis. Bacterial aliquots were taken for the enumeration of viable cells at 0,60 , and 120 minutes. Bacterial survival was expressed with reference to the initial bacteria count. Pepsin and $\mathrm{HCl}$ were obtained from Sigma (Sigma-Aldrich, Sent Louis, MO, USA). The effect of bile salts solution on bacterial survival was studied by ressuspending the harvested cells (grown in MRS medium at $37^{\circ} \mathrm{C}$ for $18 \mathrm{~h}$ ) in PBS buffer $(0.01$ $\mathrm{M} \mathrm{K}_{2} \mathrm{HPO}_{4}, 0.01 \mathrm{M} \mathrm{KH}_{2} \mathrm{PO}_{4}$ and $0.15 \mathrm{M} \mathrm{NaCl}$ ) containing $0.5 \%$ bovine bile salts and adjusting it to $\mathrm{pH} 8.0$ with $1 \mathrm{M}$ $\mathrm{NaOH}$. The suspensions were incubated at $37^{\circ} \mathrm{C}$ for up to $2 \mathrm{~h}$ with gently agitation $(58 \mathrm{rpm})$. The samples for total viable counts were taken at $0,30,60,90$, and $120 \mathrm{~min}$ and expressed with reference to the initial bacteria count.

\section{In vivo testing - abnormal toxicity, bacterial viability,} adhesiveness to the intestinal mucosa and serum lipid level

Animals: For these studies, Wistar rats (6-8 weeks old, about $200 \pm 10 \mathrm{~g}$ weight), and NMRI Ham mice (6 weeks old, 18-22 $\mathrm{g}$ weight) derived from the animal house of Galenika, Serbia, were used. The animals were housed individually under the standard conditions (temperature $21 \pm 3^{\circ} \mathrm{C}$, relative 
humidity $40 \%-70 \%, 12 \mathrm{~h}$ light/12 h dark cycle), according to the principles enunciated in the Guide for Care and Use of Laboratory Animals, (NIH publication No. 85-23). They were fed with commercial rat pellet and water ad libitum. Abnormal toxicity was tested in NMRI Ham mice. The National Ethical Committee (06/10, Faculty of Biology, University of Belgrade) approved all experimental protocols.

\section{Experimental procedure}

The abnormal toxicity test was used to assess the effects of the G1 and G3 isolates applied in a single daily oral dose of $10^{7} \mathrm{CFU} / 0.5 \mathrm{ml}$, which, calculated with reference to human body mass of $70 \mathrm{~kg}$, would correspond to the daily probiotic dose of $10^{11} \mathrm{CFU} / \mathrm{kg}$. Clinically healthy NMRI Ham laboratory mice (28) of both sexes and body mass of 18-22 g were used for the test. The mice were kept in macrolon cages, with feed and water given ad libidum. The lactobacilli were resuspended in $0.5 \mathrm{ml}$ of sterile saline and, using a gastric sonde, administered into the stomach of each of experimental animals. The test result was negative, i.e. the strain showed to be nontoxic when the mice survived the 72-hour period following the administration (12).

Studies of bacterial viability in the GIT and adhesiveness to the intestinal mucosa were conducted on 15 Wistar rats. The animals were randomly divided into three groups (G1-treated, G3-treated and control). They were fed daily through a gastric needle-tube with $1 \mathrm{ml}$ of saline containing $10^{6} \mathrm{CFU}$ of lactobacilli (treated rats) or saline (control rats) for 7 days. The total number of lactobacilli was determined by plate count on MRS agar, after anaerobic incubation at $37^{\circ} \mathrm{C}$ for $48 \mathrm{~h}$. Following lactobacilli administration, the animals were kept under strict clinical supervision, particularly in the first 4 hours. The faecal samples were taken aseptically after emission from each rat in the morning, before administration of the lactobacilli, on days 0,3 , and 7 for microbiological analysis of the microbiota. After 7 days, the animals were euthanized with increased concentration of $\mathrm{CO}_{2}$ and their organs and tissues subjected to observation. A portion of the middle part of ileum (1 cm length fragment) was taken from each animal for microbiological analysis, i.e. the assessment of bacterial adhesiveness to the intestinal mucosa. A section of the ileum was rinsed three times with saline to eliminate the faecal content and, using a sterile tweezers, spread on previously fresh prepared MRS plates and left at room temperature for $6 \mathrm{~h}$. Intestinal section was removed and the plates were incubated in anaerobic conditions at $37^{\circ} \mathrm{C}$ for $48 \mathrm{~h}$. The obtained material was purified on MRS agar. DNA was isolated from 174 individual colonies both from faecal samples and from the surface of the intestinal mucosa and PCR with UNI16SF and UNI16SR was performed. Sequencing of obtained PCR fragments was used to verify/identify re-isolated bacteria. The PCR reactions and the sequencing were performed as described above.

On day 7 , blood samples were taken from the jugular vein and biochemical serum tests were performed, i.e. serum cholesterol and triglyceride levels were assessed, as well as alkaline phosphatase (ALP) activity. Biochemistry of triglycerides, cholesterol and ALP activity was tested spectrophotometrically using the instrument Abbott Architect C8000 (Abbott Laboratories. Abbott Park, IL, USA). Serum triglycerides were assayed colorimetrically with an enzyme that produces hydrogen peroxide $(15,29)$. Cholesterol was assayed colorimetrically using cholesterol esterase and cholesterol oxydase (5). ALP was assayed spectrophotometrically, according to the modified method using nitrophenyl phosphate as the substrate (35).

\section{Statistical data analyses}

Presented results are the mean values calculated based on three independent measurement results: $(\bar{x} \pm s)$, where: $\bar{x}$ Mean value calculated on three independent measurement results $s$ - Standard deviation under the conditions of repeatability. 


\section{RESULTS}

Oral swabs (16 samples) from healthy subjects, between 10 and 50 years old, were used for the isolation of a new potentially probiotic lactobacilli. Preliminary identification of 98 isolates (selected out of 167 colonies based on colony morphology) was relied on the results obtained after morphological, physiological, and biochemical testing. According to the results obtained, 20 different groups of lactobacilli were formed. One representive from each group was chosen for antimicrobial testing and two out of 20 isolates proved inhibitory effects against different indicator strains. The isolates showing antimicrobial activity were assigned as G1 (40-year old female) and G3 (12-year old child) and selected for the further investigations. Subsequently, the two selected isolates were more accurately identified to the species level by sequencing of the complete $16 \mathrm{~S}$ rRNA genes. According to the nucleotide sequence, strain G1 was identified as $L$. plantarum/pentosus and strain G3 as L. casei. Finally, using multiplex PCR assay, G1 isolate was recognized as $L$. plantarum.
Both indigenous isolates L. plantarum $\mathrm{G} 1$ and $L$. casei $\mathrm{G} 3$ were able to inhibit the growth of $S$. aureus ATCC 6538-P, E. coli ATCC 8739, P. aeruginosa ATCC 9027, S. abony NTCC 6017, and C. sporogenes ATCC 19404. Nevertheless, G1 and G3 failed to inhibit C. albicans ATCC 10231. Unlike G1, no antimicrobial activity of G3 was detected against the indicator strains B. cereus ATCC 11778. No cross-inhibition among the antimicrobial producers was observed. The cell free filtrate of G1 showed strong antimicrobial activity against all used pathogenic bacteria, particularly against $S$. aureus (Table 1). In order to investigate the proteinaceous nature of the antimicrobial substances (bacteriocin or bacteriocin-like substance), the filtrate obtained from overnight culture was neutralised and the enzyme Proteinase-K was added. No zone of inhibition was detected only in the case when G1 cell free filtrate was used against indicator S. aureus ATCC 6538-P. Lactobacillus casei G3 did not exhibit bacteriocin activity against the selected indicator strains (Table 1). According to HPLC analysis LA concentration of cell free filtrates were $11.85 \mathrm{~g} / 1$ and $11.41 \mathrm{~g} / 1$ for L. plantarum G1 and L. casei G3, respectively.

Table 1. Antimicrobial and bacteriocin (*) activity of cells free filtrate obtained from L. plantarum G1 and L. casei G3 overnight cultures.

\begin{tabular}{|c|c|c|c|c|}
\hline Indicator strain & $\begin{array}{c}\text { L. plantarum G1 } \\
(\mathrm{AU} / \mathrm{ml}) \\
\text { before neutralisation of } \\
\text { lactic acid }\end{array}$ & $\begin{array}{c}\text { L. plantarum G1 } \\
(\mathrm{AU} / \mathrm{ml})\end{array}$ & $\begin{array}{c}\text { L. casei G3 } \\
(\mathrm{AU} / \mathrm{ml}) \\
\text { before neutralisation of } \\
\text { lactic acid }\end{array}$ & $\begin{array}{c}\text { L. casei G3 } \\
(\mathrm{AU} / \mathrm{ml}) \\
\text { after neutralisation } \\
\text { of lactic acid }\end{array}$ \\
\hline *S. aureus ATCC 6538-P & 256 & $* 64$ & 64 & 0 \\
\hline E. coli ATCC 8739 & 64 & 0 & 16 & 0 \\
\hline P. aeruginosa ATCC 9027 & 64 & 0 & 16 & 0 \\
\hline *S. abony NTCC 6017 & 64 & $* 32$ & 8 & 0 \\
\hline C. sporogenes ATCC 19404 & 16 & $* 8$ & 8 & 0 \\
\hline B. cereus ATCC 11778 & 8 & 0 & - & - \\
\hline C. albicans ATCC 10231 & - & - & - & - \\
\hline
\end{tabular}

The effect of single L. plantarum G1 or L. casei G3 on S. aureus ATCC 6538-P, E. coli ATCC 8739, and S. abony NTCC 6017 growth was observed to be dependent of the pathogen (Table 2). When G1 was mixed with these pathogens, the growth of the pathogen was $6.5 \log$ units lower for $S$. aureus, $2.1 \log$ units lower for E. coli and $0.8 \log$ units for $S$. abony, when compared to the growth of the pure culture of the pathogen. On the other hand, the effect of the pathogen growth 
reduction was in the range of 1-2 log units when G3 was used. The cumulative effect of G1 and G3 $\left(10^{7} \mathrm{CFU} / \mathrm{ml}\right)$ resulted in the reduction of $S$. aureus growth for $7.5 \log$ units, of $E$. coli for $7.2 \log$ units, and of $S$. abony for $5.7 \log$ units, when compared to control cultures. The results for mixed cultures of G1 and G3 $\left(10^{10} \mathrm{CFU} / \mathrm{ml}\right)$ showed that the complete inhibition of pathogenic bacteria growth was observed after $24 \mathrm{~h}$ incubation.

Table 2. The effect of L. plantarum G1 and L. casei G3 on the growth of S. aureus ATCC 6538-P, E. coli ATCC 8739 and S. abony NTCC 6017.

\begin{tabular}{|c|c|c|c|c|c|}
\hline Indicator strain & $\begin{array}{c}\text { Indicator strain } \\
\text { (control) }\end{array}$ & $\begin{array}{c}\text { Indicator strain with } \\
10^{7} \mathrm{CFU} / \mathrm{ml} \\
\text { G1 }\end{array}$ & $\begin{array}{c}\text { Indicator strain } \\
\text { with } 10^{7} \mathrm{CFU} / \mathrm{ml} \\
\text { G3 }\end{array}$ & $\begin{array}{c}\text { Indicator strain } \\
\text { with } 10^{7} \mathrm{CFU} / \mathrm{ml} \\
\text { G1 +G3 }\end{array}$ & $\begin{array}{c}\text { Indicator strain } \\
\text { with } 10^{10} \mathrm{CFU} / \mathrm{ml} \\
\mathrm{G} 1+\mathrm{G} 3\end{array}$ \\
\hline $\begin{array}{l}\text { S. aureus } \\
\text { ATCC 6538-P }\end{array}$ & $6.5 \pm 0.10 \times 10^{8}$ & $2.0 \pm 0.08 \times 10^{8}$ & $7.1 \pm 0.13 \times 10^{8}$ & $2.1 \pm 0.09 \times 10^{1}$ & 0 \\
\hline $\begin{array}{l}\text { E. coli } \\
\text { ATCC } 8739\end{array}$ & $4.8 \pm 0.09 \times 10^{8}$ & $4.4 \pm 0.10 \times 10^{6}$ & $3.6 \pm 0.10 \times 10^{7}$ & $3.3 \pm 0.09 \times 10^{1}$ & 0 \\
\hline $\begin{array}{l}\text { S. abony } \\
\text { NTCC } 6017\end{array}$ & $1.2 \pm 0.05 \times 10^{8}$ & $2.2 \pm 0.06 \times 10^{7}$ & $9.9 \pm 0.12 \times 10^{6}$ & $3.7 \pm 0.08 \times 10^{1}$ & 0 \\
\hline
\end{tabular}

Each value represents mean $+/-\mathrm{SEM}(\mathrm{n}=3)$

Bacterial survival was tested in the conditions similar to those in the proximal part of the gastrointestinal tract, at time intervals corresponding to the actual presence of lactobacilli in the intestines. Incubated at $37^{\circ} \mathrm{C}$, both isolates showed a high degree of the survival in AGJ and in the solution containing $0.5 \%$ bovine bile salts. After 120-min exposure of strains to
AGJ, a decreased count of viable G1 by $1.94 \log$ CFU/ml, and G3 by $1.74 \log \mathrm{CFU} / \mathrm{ml}$ was observed (Fig. 1A). In addition, after 120-min exposure to the bovine bile salts solution, viable G1 and G3 decreased, respectively, $0.45 \log \mathrm{CFU} / \mathrm{ml}$, and 0.22 $\log$ CFU/ml (Fig. 1B).
A

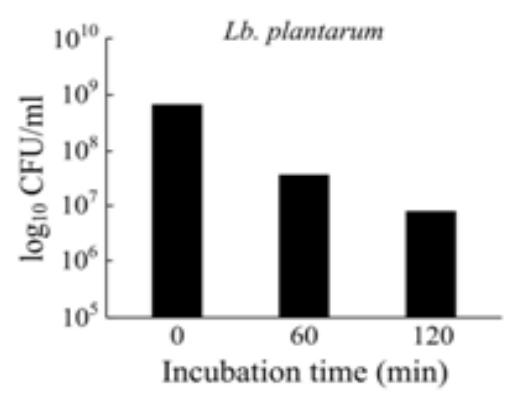

B

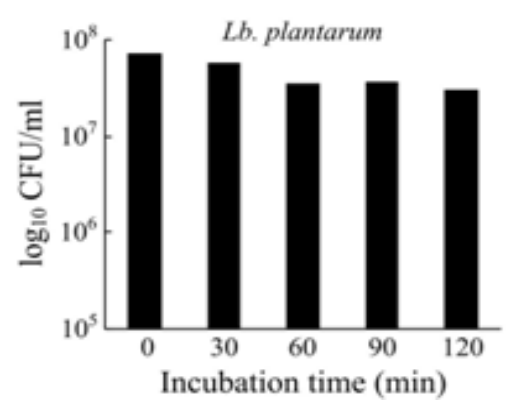

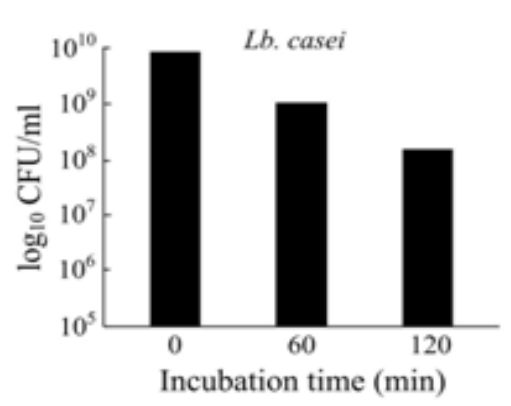

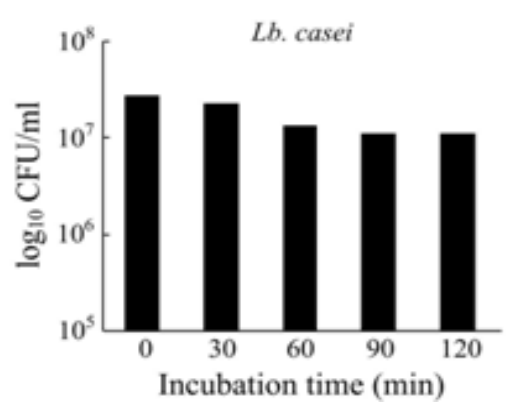

Figure 1. Survival of L. plantarum G1 and L. casei G3 in simulated artificial gastric juice at pH 2.0 (A) and in the solution containing $0.5 \%$ bovine bile salts $(\mathrm{B})$. 
Studies of abnormal toxicity did not reveal any visible changes in the behaviour of NMRI Ham mice treated with lactobacilli. In addition, all mice survived the treatment with lactobacilli.

The composition of microbial populations in the faecal samples of Lactobacillus-treated and control animals was also investigated and representatives of the genera Enterococcus sp., Escherichia coli and Clostridium sp. were evaluated on selective media. After 7-day treatment of Wistar rats with G1, a significant decrease (in $3 \mathrm{log}$ units) in E. coli populations was estimated. No important changes in enterococci and clostridia counts were detected.

Additionally, after 7 days of lactobacilli administration, the strains G1 and G3 were re-isolated from the faecal samples, as well as from the ileum surface. Among 174 colonies recovered from both, faecal samples and ileum surface, 10 colonies were confirmed as G1 and 10 as G3 by $16 \mathrm{~S}$ rDNA sequencing.

Biochemical analysis of blood samples revealed the influence of G1 and G3 on lipid metabolism in rats. Compared to the control group, the 7-day treatment with lactobacilli evidently decreased triglycerides and cholesterol levels, as well as the ALP activity. In the case of G1-treated rats, a decrease in triglycerides level of $28 \%$ (from $1.44 \mathrm{mM} / \mathrm{l}$ to $1.04 \mathrm{mM} / \mathrm{l}$ ), cholesterol level of $27 \%$ (from $1.86 \mathrm{mM} / 1$ to $1.35 \mathrm{mM} / \mathrm{l}$ ), and ALP activity of $17 \%$ (from $512.50 \mathrm{U} / 1$ to $420.00 \mathrm{U} / \mathrm{l}$ ) was demonstrated. However in G3-treated rats a decrease in triglycerides level of $35 \%$ (from $1.44 \mathrm{mM} / 1$ to $0.95 \mathrm{mM} / \mathrm{l}$ ), cholesterol level of $19 \%$ (from $1.86 \mathrm{mM} / 1$ to $1.51 \mathrm{mM} / \mathrm{l}$ ), and ALP activity of $21 \%$ (from $512.50 \mathrm{U} / 1$ to $395.00 \mathrm{U} / \mathrm{l}$ ), was detected (Table 3).

Table 3. Lipid content and ALP activity in serum of Wistar rats treated with lactobacilli.

\begin{tabular}{cccc}
\hline & $\begin{array}{c}\text { Cholesterol } \\
(\mathbf{m M} / \mathbf{l})\end{array}$ & $\begin{array}{c}\text { Triglycerides } \\
(\mathbf{m M} / \mathbf{l})\end{array}$ & $\begin{array}{c}\text { Alkaline phosphatase (ALP) } \\
(\mathbf{U} / \mathbf{l})\end{array}$ \\
\hline Control & $1.86 \pm 0.09$ & $1.44 \pm 0.21$ & $512.50 \pm 33.77$ \\
L. plantarum $\mathrm{G} 1$ & $1.35 \pm 0.06$ & $1.04 \pm 0.11$ & $420.00 \pm 29.44$ \\
L. casei $\mathrm{G} 3$ & $1.51 \pm 0.03$ & $0.95 \pm 0.02$ & $395.50 \pm 6.06$ \\
\hline
\end{tabular}

Each value represents mean $+/$ - SEM $(n=3)$

\section{DISCUSSION}

Preservation of the microbiological balance in the human gastrointestinal tract is of great importance, since disturbed equilibrium, especially between Lactobacillus as one of the most important Gram-positive and other mainly Gram-negative bacteria might result in the occurrence of various diseases $(8$, 16). An estimated number of approximately 100 to 125 species of the Lactobacillus genus exist and the number is constantly increasing, due to the isolation and identification of new lactobacilli species $(10,34)$. Since lactobacilli are mainly used in pharmaceutical and food industry, precise identification to the species level, as well as testing their probiotic features, are needed. Species like L. acidophilus, L. plantarum, $L$. bulgaricus, L. casei, L. rhamnosus, and L. fermentum are among the most abundant lactobacilli used in probiotic products. In this paper, two human isolates that showed antimicrobial activity were analyzed. The isolate G1, originated from an adult oral mucosa, was identified as $L$. plantarum, and the isolate G3, originated from a child oral mucosa, was identified as $L$. casei. It is well known that $L$. plantarum and L. casei form the dominant oral microbiota of healthy individuals, while other lactobacilli, like L. salivarius, L. acidophilus, L. oris, and L. fermentum are also frequently found $(2,7)$.

Our in vitro studies showed that G1 and G3 expressed antimicrobial (especially G1) and bacteriocin activity (only G1) against the pathogenic strain S. aureus ATCC 6358-P. 
Liasi and coauthors (24) demonstrated that L. plantarum LA22 inhibited the growth of bacteria S. aureus, B. cereus, E. coli, Salmonella enterica, and Listeria monocytogenes. These results were also corroborated with other literature data stating that some L. plantarum strains, besides L. paracasei, L. rhamnosus, and L. salivarius show the greatest antimicrobial activities (6, 11, 23). The strain G1 expressed its antimicrobial activity against the pathogenic $S$. aureus, which is in correlation with the results obtained for antimicrobial activity of $L$. plantarum LA22 and L. paracasei subsp. paracasei BGBUK2-16 $(26,7)$. Moreover, according to Todorov and Dicks (36) L. plantarum isolated from molasses produced two thermostable bacteriocins (ST28MS and ST26MS) that inhibited the growth of a broad spectrum of pathogens, including, S. aureus, E. faecalis, E. coli, P. aeruginosa, and Acinetobacter baumanii. The results obtained from our study strongly indicate that the antimicrobial activity of G1 is the result of a bacteriocin-like activity. The nature of this bacteriocin-like substance(s) will be a focus of our future studies. We can only speculate that the antimicrobial activity of G1 may be the result of the cumulative effect of lactic acid and bacteriocin, while the antimicrobial effect of G3 is the result of lactic acid activity alone. In addition, complete growth reduction of $S$. aureus ATCC 6538-P, E. coli ATCC 8739, and S. abony NTCC 6017 pathogens was obtained when a mixed culture of $\mathrm{G} 1$ and $\mathrm{G} 3$ at $10^{10} \mathrm{CFU} / \mathrm{ml}$ concentration was used.

The resistance to specific conditions in stomach and duodenum is another important factor that could explain the efficiency of some probiotic preparations. When compared to the literature data, both strains used in our study showed a high degree of viability in the simulated conditions of the proximal and the distal part of the gastrointestinal tract $(24,34)$. Gastric digestion at pH 2 did not significantly affect the survival of G1 and G3 and even after $120 \mathrm{~min}$ the amount of viable bacteria decreased by less than $2 \log$ units. In similar experiment, Pereira and Gibson (32) showed that the strain L. casei Shirota exhibited a significant decrease of 3-4 log units after $60 \mathrm{~min}$ of exposure to gastric digestion. The proposed bile concentration to which a probiotic strain should be tolerant varies from 0.15 to $0.6 \%$ (14). Lactobacilli tested in this study survived in the presence of $0.5 \%$ bile salts and appear to be resistant to the intestinal conditions. Overall, obtained results indicate that the viability of G1 and G3 strains in simulated GIT conditions was sufficient for their successful and massive passage through this system.

To assess the safety of G1 and G3 strains, NMRI Ham mice were fed with bacteria in a dose 100 times greater than the average most frequently administered probiotic dose for the oral use. No feeding or behavioural changes were observed in the treated mice, when compared to the control group. None of the treated mice died during $72 \mathrm{~h}$ following lactobacilli administration. Therefore, G1 and G3 most probably did not induce toxic effects, i.e. they were considered safe after the oral administration. In vivo studies on Wistar rats showed good viability of lactobacilli in the GIT. Namely, G1 and G3 strains were re-identified in faecal samples of the treated Wistar rats. Moreover, a lower E. coli count in faecal samples was seen in Wistar rats treated with G1. In addition, G1 and G3 strains were also re-identified in the material taken from the surface of ileum mucosa of Wistar rats. These results could be an indicator of good colonization ability and bacterial adhesiveness of $\mathrm{G} 1$ and $\mathrm{G} 3$ to the intestinal mucosa as described previously (28).

The analysis of biochemical parameters of blood samples revealed that the application of G1 and G3 improves lipid metabolism and hepatic function. It was shown that both strains from our study reduced the content of serum lipids, including cholesterol and triglycerides, in Wistar rats. These results comply with literature data indicating that specific strains of lactobacilli, such as L. casei ASCC 292, present hypolipidemic effect through different mechanisms, like cholesterol removal through cholesterol micelles destabilization and, secondly, through precipitation of the cholesterol with bile acids $(9,21$, 25,32 ). These mechanisms are responsible for the reduction of 
atheromatous plaque, thus playing a key role in the prevention of cardiovascular diseases development (30). The ALP is one of four liver enzymes included in most routine laboratory tests, because their raised levels may be an indication of a liver disease. Also, G1 and G3 lowered the activity of liver enzymes, such as alkaline phosphatase (ALP), indicating possible general improvement of the liver function.

In conclusion, the results of our study suggest that the indigenous oral strains L. plantarum G1 and L. casei G3 exhibit high resistance to GIT conditions, including low $\mathrm{pH}$ and bile salts, antimicrobial activity against different human pathogens, reduce serum cholesterol and triglyceride levels and decrease the activity of ALP. Additionally, both strains showed high viability in the GIT of Wistar rats and revealed to be safe for the consumption when Ham mice were used as a model organism. Finally, G1 and G3 strains have a promising probiotic potential and after more detailed analyses, including clinical trials, could be applied as nutraceuticals or biotherapeuticals.

\section{ACKNOWLEDGEMENT}

These investigations were supported by the Ministry of Education and Science, Republic of Serbia (grant No. 451-010065/2008-01/28 and grant No. 173019).

\section{REFERENCES}

1. Aboderin, F.I.; Oyetayo, V.O. (2006). Haematological studies of rats fed different doses of probiotic Lactobacillus plantarum, isolated from fermenting corn slurry. Pakistan. J. Nutr. 5, 102-105.

2. Ahrne, S.; Nobaek, S.; Jeppsson, B.; Adlerberth, I.; Wold, A.E.; Molin, G. (1998). The normal Lactobacillus flora of healthy human rectal and oral mucosa. J. Appl. Microbiol. 85, 88-94.

3. Adams, M.R.; Hall, C.J. (1988). Growth inhibition of food-borne pathogens by lactic and acetic acids and their mixtures. Int. J. Food Sci. Technol. 23, 287-292.

4. Al-Allaf, M.A.H.; Al-Rawi, A.M.M.; Al-Mola, A.T. (2009). Antimicrobial activity of lactic acid bacteria isolated from minced beef meat against some pathogenic bacteria. Iraqi. J. Vet. Sci. 23, 115-117.

5. Allain, C.C.; Poon, L.S.; Chan, C.S.H.; Richmond,W.; Fu, P.C. (1974).
Enzymatic determination of total serum cholesterol. Clin. Chem. 20, 470475 .

6. Amin, M.; Jorfi, M.; Khorsravi, A.D.; Samarbafzadeh, A.R.; Farajzadeh, S. (2010). Isolation and identification of Lactobacillus casei and Lactobacillus plantarum from plants by PCR and Detection of their antibacterial activity. J. Biol. Sci. 9, 810-814.

7. Badet, C.; Thebaud, N.B. (2008). Ecology of Lactobacilli in the Oral Cavity: A Review of Literature. Microbiol. J. 2, 38-48.

8. Botina, S.G.; Koroban, N.V.;Klimina, K.M.; Glazova, A.A.; Zakharevich, N.V.; Zinchenko, V.V.; Danilenko, V.N. (2010). Genetic diversity of the genus Lactobacillus bacteria from the human gastrointestinal microbiome. Russian J. Gen. 46, 1399-1406.

9. Brashears, M.M.; Gilliland,S.E.; Buck, L.M. (1998). Bile salt deconjugation and cholesterol removal from media by Lactobacillus casei. J. Dairy Sci. 81, 2103-2110.

10. Canchaya, C.; Claesson, M.J.; Sinderen, van G.D.; Toole, W. O. ( 2006). Diversity of the genus Lactobacillus comparative genomics of five species. Microbiol. 152, 3185-3196.

11. Devine, D.A.; Marsch, P. (2009). Prospects for the development of probiotics and prebiotics for oral applications. J. Oral Microbiol. doi: 10.3402/jom.v1i0.1949.

12. European Pharmacopeia 6.0, p. 165. (2008). Abnormal toxicity.

13. FAO/WHO. (2002). Guidelines for the evaluation of probiotics in food drafting guidelines for the evaluation of probiotics in food. Report of a joint $\mathrm{FAO} / \mathrm{WHO}$ working group on drifting guidelines for the evaluation of probiotics in food. London, Ont. Canada.

14. Fernandez, M.; Boris, S.; Barbes, C. (2003). Probiotic properties of human lactobacilli strains to be used in the gastrointestinal tract. J. Appl. Microbiol. 94, 449-455.

15. Fossati, P.A.; Prencipe, L. (1983). Serum triglycerides determined colorimetrically with an enzyme that produces hydrogen peroxide. Clin. Chem. 29, 538-542.

16. Goel, A.K.; Dilbaghi, N.; Kamboj, D.V.; Singh, L. (2006). Probiotics: Microbial therapy for health modulation. Defence Sci J. 56, 513-529.

17. Graf, C.; Sarasin, F.P.(2007). Efficacy and safety of probiotics. Rev. Med. Suisse. 3, 2350-2354.

18. He, X.; Tian, Y.; Guo L.; Lux R.; Zusman D.R.; Shi W. (2010). OralDerived Bacterial Flora Defends Its Domain by Recognizing and Killing Intruders-A Molecular Analysis Using Escherichia coli as a Model Intestinal Bacterium. Microb. Ecol. 60, 655-664.

19. Huh, Y.S.; Jun, Y.S.; Hon, Y.K.; Song, H.; Lee,S.Y.; Hong, W.H. (2006). Effective purification of succinic acid from fermentation broth produced by Mannheimia succinciproducens. Proc. Biochem. 41, 14611465.

20. Ishibashi, N.; Yamazaki, S. (2001). Probiotics and safety. Am J Clin Nutr. 73, 465S-470S.

21. Kapila, S.; Vibha, S.; Sinha, P.R. (2006). Antioxidative and 
22. hypocholesterolemic effect of Lactobacillus casei ssp. casei (biodefensive properties of lactobacilli). Indian J. Med. Sci. 60, 361-370.

23. Kaushik, J.K.; Kumar, A.; Duary, R.K.; Mohanty, A.K.; Grover, S.; Batish, K. (2009). Functional and probiotic attributes of an indigenous isolate of Lactobacillus plantarum. PLoS One doi: 10.1371/journal.pone.0008099.

24. Koll-Klais, P.; Mandar, R.; Leibur, E.; Marcotte, H.; Hammarstrom, L.; Mikelsaar, M. (2005). Oral lactobacilli in chronic periodontitis and periodontal health species composition and antimicrobial activity. Oral. Microbial. Immunol. 6, 354-361.

25. Liasi, S.A.; Azmi, T.I.; Hassan, M.D.; Shuhaimi, M.; Rosfarizan, M.; Ariff, A.B. (2009). Antimicrobial activity and antibiotic sensitivity of three isolates of lactic acid bacteria from fermented fish product. Budi. Malaysian J. Microbiol. 51, 33-37.

26. Liong, M.T.; Shah, N.P. (2005). Acid and bile tolerance and cholesterol removal ability of lactobacilli strains. J. Dairy Sci. 88, 55-66.

27. Lozo, J.; Vukasovic, M.; Strahinic, I.; Topisirovic, L. (2004). Characterization and antimicrobial activity of bacteriocin 217 produced by natural isolate Lactobacillus paracasei subsp. paracasei BGBUK216. J. Food Protection. 67, 2727-27345.

28. Matsuda, K.; Tsuji, H.; Asahara, T.; Matsumoto, K.; Takada, T.; Nomoto. K. (2009). Establishment of an Analytical System for the Human Faecal Microbiota, Based on Reverse Transcription-Quantitative PCR Targeting of Multicopy rRNA Molecules. Appl. Environ. Microbiol. 75 (7), 1961-1969.

29. Minelli, E.B.; Benini, A.; Marzotto, M.; Sbarbati, A.; Ruzzenente, O.; Ferrario, R.; Hendriks, H.; Dellaglio, F. 2004. Assessment of novel probiotic Lactobacillus casei strains for the production of functional dairy foods. Int. Dairy J. 14, 723-736.

30. McGowan, M.W.; Artiss, J.D.; Strandbergh, D.R.; Zak, B. (1983). A peroxidase-coupled method for the colorimetric determination of serum triglycerides. Clin. Chem. 29, 2077-2080.

31. Naruszewicz, M.; Johansson, M.L.; Zapolska-Downar, D.; Bukowska, H. (2002). Effect of Lactobacillus plantarum 299v on cardiovascular disease risk factors in smokers. Am. J. Clin. Nutr. 76, 1249-1255.

32. Oh, S.; Kim, S.H.; Worobo, R.W. 2000. Characterization and purification of a bacteriocin produced by a potential probiotic culture, Lactobacillus acidophilus 30SC. J. Dairy Sci. 83, 2747-2752.

33. Pereira, D.I.; Gibson, G.R. (2002). Cholesterol assimilation by lactic acid bacteria and bifidobacteria isolated from the human gut. Appl. Environ. Microbiol. 68, 4689-4693.

34. Pham, M.; Lemberg, D.A.; Day, A.S. (2008). Probiotics: sorting the evidence from the myths. Med. J. Aust. 188, 304-308.

35. Pot, B.; Tsakalidou, E. (2009). Taxonomy and metabolism of Lactobacillus. In Lactobacillus Molecular Biology:From genomics to probiotics. Ljungh A., and Wadstrom, T. (eds) Norfolk, UK: Caister Academic Press, p. 3-59.

36. Tietz, N.W. (1995). Quantitative determination of alkaline phosphatase. In Clinical Guide to Laboratory Tests. Wu, A., 3rd ed. Saunandders, Philadelphia, PA.

37. Todorov, S.D.; Dicks, L.M.T. (2005). Lactobacillus plantarum isolated from molasses produces bacteriocins active against Gram-negative bacteria. Enzyme Microb. Technol. 36, 318-326.

38. Torriani, S.; Felis, E.G.; Dellagio, F. (2001). Differentiation of Lactobacillus plantarum, Lact. pentosus, and Lact. paraplantarum by recA gene sequence analysis and multiplex PCR assay with $r e c A$ genederived primers. Appl. Environ. Microbiol. 67, 3450-3454.

39. Veljovic, K.; Terzic-Vidojevic, A.; Vukasinovic, M.; Strahinic, I.; Begovic, J.; Lozo, J.; Ostojic, M.; Topisirovic, L. (2007). Preliminary characterization of lactic acid bacteria isolated from Zlatar cheese. $J$. Appl. Microbiol. 103, 2142-2152.

40. Walter, J. (2008). Ecological Role of Lactobacilli in the Gastrointestinal Tract: Implications for Fundamental and Biomedical Research. Appl. Environ. Microbiol. 74, 4985-4966.

41. Wang, Y.; Xu, N.; Xi, A.; Ahmed, Z.; Zhang, B.; Bai, X. (2009). Effects of Lactobacillus plantarum MA2 isolated from Tibet kefir on lipid metabolism and intestinal microflora of rats fed on high-cholesterol diet. Appl. Microbiol. Biotechnol. 84, 341-347. 